\title{
Cognitive cooperation groups mediated by computers and internet present significant improvement of cognitive status in older adults with memory complaints: a controlled prospective study
}

Grupos de Cooperação Cognitiva mediados pelo uso de computadores e internet mostram uma melhora significativa no estado cognitivo em idosos com queixas de memória: estudo controlado prospectivo

Rodrigo de Rosso Krug', Anna Quialheiro Abreu da Silva ${ }^{2,3}$, Ione Jayce Ceola Schneider ${ }^{4}$, Luiz Roberto Ramos ${ }^{5}$, Eleonora d'Orsi ${ }^{1,3}$, André Junqueira Xavier ${ }^{2,3}$.

\begin{abstract}
Objective: To estimate the effect of participating in cognitive cooperation groups, mediated by computers and the internet, on the Mini-Mental State Examination (MMSE) percent variation of outpatients with memory complaints attending two memory clinics. Methods: A prospective controlled intervention study carried out from 2006 to 2013 with 293 elders. The intervention group $(n=160)$ attended a cognitive cooperation group (20 sessions of 1.5 hours each). The control group $(n=133)$ received routine medical care. Outcome was the percent variation in the MMSE. Control variables included gender, age, marital status, schooling, hypertension, diabetes, dyslipidaemia, hypothyroidism, depression, vascular diseases, polymedication, use of benzodiazepines, exposure to tobacco, sedentary lifestyle, obesity and functional capacity. The final model was obtained by multivariate linear regression. Results: The intervention group obtained an independent positive variation of $24.39 \%$ (CI 95\% = 14.86/33.91) in the MMSE compared to the control group. Conclusion: The results suggested that cognitive cooperation groups, mediated by computers and the internet, are associated with cognitive status improvement of older adults in memory clinics.
\end{abstract}

Keywords: rehabilitation; cognition; computers; aged.

RESUMO

Objetivo: Avaliar o efeito da participação em Grupos de Cooperação Cognitiva mediados por computadores e internet na variação do Mini-Exame de Estado Mental (MEEM) de pacientes ambulatoriais com queixas de memória, participantes de duas clínicas de memória. Métodos: Estudo prospectivo de intervenção controlada, realizado em 2006-2013 com 293 idosos. O grupo de intervenção ( $n=160$ ) participou de um Grupo de Cooperação Cognitiva (20 sessões de 1,5 horas cada). 0 grupo controle $(n=133$ ) recebeu acompanhamento médico. O desfecho foi a variação percentual no MEEM. As variáveis de controle incluíram genêro, idade, estado civil, escolaridade, hipertensão, diabetes, dislipidemia, hipotiroidismo, depressão, doenças cardiovasculares, polimedicação, uso de benzodiazepínicos, exposição ao tabaco, sedentarismo, obesidade e capacidade funcional. Todas as variáveis foram coletadas antes e após a intervenção. 0 modelo multivariado final foi obtido por regressão linear múltipla. Resultados: 0 grupo de intervenção obteve variação positiva independente de 24,39\% (IC95\% = 14.86/33.91) no MEEM em relação ao grupo controle. Conclusão: Os resultados deste estudo sugerem que o grupo de intervenção, mediados por computadores e internet estão associados com melhora do status cognitivo em idosos de clínicas de memória. Palavras-chave: Reabilitação; cognição; computadores; idoso.

\footnotetext{
1Universidade Federal de Santa Catarina, Centro de Ciências da Saúde, Programa de Pós-Graduação em Ciência Médicas, Florianópolis SC, Brasil; UUniversidade do Sul de Santa Catarina, Palhoça SC, Brasil;

${ }^{3}$ Universidade Federal de Santa Catarina, Centro de Ciências da Saúde, Programa de Pós-Graduação em Saúde Coletiva, Florianópolis SC, Brasil; ¿Universidade Federal de Santa Catarina, Curso de Fisioterapia, Programa de Pós-Graduação em Ciências da Reabilitação, Araranguá SC, Brasil; ${ }^{5}$ Universidade de Federal de São Paulo, Programa de Pós-Graduação em Saúde Coletiva, São Paulo SP, Brasil.

Correspondence: Rodrigo de Rosso Krug; Centro de Ciências da Saúde, bloco A, sala 126, Campus Universitário; 88040-410 Florianópolis SC; Brasil; E-mail: rodrigo_krug@hotmail.com

Conflict of interest: There is no conflict of interest to declare.

Received 22 March 2016; Received in final form 15 November 2016; Accepted 27 December 2016.
} 
Individuals aged 60 years and older who report subjective memory problems are at high risk for cognitive decline, further mild cognitive impairment, and dementia. They require exhaustive assessment and follow-up care ${ }^{1,2}$. Cognitive decline, which can begin as early as 45 years of age, causes difficulties in learning, memory, language, orientation, and executive functions ${ }^{3}$.

A memory clinic is an outpatient interdisciplinary service organized to prevent, diagnose, coordinate care and provide autonomy and independence for persons suffering from cognitive impairment and dementia ${ }^{4}$. It can also provide non-pharmacological care such as psychosocial interventions and cognitive stimulation ${ }^{5}$. Memory clinics worldwide should share their best practices, assessment, early interventions, information on innovative practices, teaching, and research ${ }^{5}$.

Consistent evidence arising from controlled and randomized clinical trials and meta-analysis shows that various forms of cognitive stimulating activities have a delaying effect on cognitive decline, even among those with mild cognitive impairment or initial dementia $a^{6-9}$. Decreasing the impact of known risk factors (such as diabetes, hypertension, obesity, depression, having an unhealthy diet or sedentary lifestyle, smoking, and alcohol abuse), and providing better educational opportunities and cognitive activities can prevent one in three cases of Alzheimer's disease ${ }^{10}$.

Possibly because of this, the incidence and prevalence of dementia appears to be stabilizing, or even decreasing, in high income countries ${ }^{11}$. Among the factors suggested as responsible for this are increased income with its resulting reduction of vulnerability, higher levels of education, and the reduction of cardiovascular risk factors ${ }^{12,13}$. Preventive multidomain measures focused on known risk factors and an incentive for physical, cognitive, and social activity seem to decrease cognitive decline and its consequences ${ }^{14}$.

The skill of using computers and the internet is called digital literacy and is defined as the ability to plan, execute and evaluate actions using digital instruments, such as searching the internet, and sending and receiving messages to solve daily problems. Digital literacy can mitigate physical, mental and socioeconomic limitations associated with ageing, allowing people to participate and cooperate in society, and share their material and symbolic wealth within a context of active ageing ${ }^{15}$. A cohort study with 5,506 Australian men between 69 and 87 years old found a reduction in the incidence of dementia in older adults who used computers, even after adjusting for age, education, depression, and health problems ${ }^{15}$. Digital literacy generates greater interaction with friends and/or family members, greater integration into modern society, increases self-esteem, and can maintain cognitive capacity ${ }^{16-18}$. In addition to that, the English Longitudinal Study on Ageing showed stabilization and delay of cognitive decline resulting from everyday use of computers and the internet. This occurred in both middle aged individuals and the elderly, including those with a lower cognitive capacity ${ }^{19}$.
The objective of this study was to estimate the effect of participating in cognitive cooperation groups mediated by computers and the internet, on the Mini-Mental State Examination (MMSE) percent variation of outpatients with memory complaints attending two memory clinics.

\section{METHODS}

\section{Study design, population and sample}

This was a non-randomized prospective controlled intervention study carried out from 2006 to 2013 . The population of this study consisted of community dwelling older adults (both genders) aged 60-85 years old, in two university memory clinics in southern Brazil. All participants reported subjective memory complaints and lived independently in the community. The intervention group (IG) comprised those who accepted the invitation to attend the cognitive cooperation groups; the control group (CG) comprised those who did not, but agreed to be interviewed for the study. All participants received medical follow-up and guidelines regarding the practice of healthy habits in terms of physical activity, nutrition, and intellectual activity. The exclusion criteria were: uncontrolled acute or chronic disease, severe sensory disabilities (visual and hearing) and a previous clinical diagnosis of dementia or mild cognitive impairment. All participants with 22 points or less in the first MMSE (MMSE1) were also excluded.

During the study, each patient in both groups attended at least four appointments at the memory clinics.

The cognitive cooperation groups aimed to compensate for, and stimulate cognitive impairments via interaction mediated by digital instruments (computers and the internet) in a cooperative enviroment. The groups were guided by assistants, who teach basic computer use through an errorless methodology ${ }^{20}$. There were 20 sessions of 1.5 hours each, twice a week. Previously-trained undergraduate students from the medical school (assistants) conducted the sessions in computer labs; each group had 15 - 20 participants and one assistant for every four participants. This was a sustainable program because the students learn how to deal with, and care for, older people as a part of their curriculum. This is a key consideration in terms of cost effectiveness, implementation and sustainability 5 . The cognitive cooperation groups methodology was based on learning how to use the mouse, free drawing tools, picture viewers, games, browsers, hypertextual navigation, email, and social networking. At the end of each session, there was a group discussion about the learning process, progress and difficulties, both those related to the session itself, and the awareness of changes in the participants' daily lives ${ }^{21}$. This session was fundamental for the participants and the assistants because it was the moment when attention, engagement, elaborative encoding, resilience and meaningfulness of the activities are evaluated, and the sharing of opinions was a part of the cooperation process. The intervention performed in this study represents 
a new methodology developed by Krug et al. ${ }^{22}$. The cognitive cooperation groups sessions were different every day, and were planned by taking into account the evolution of the class and the comments shared by the participants at the end of each encounter. The sessions were planned by the academic medical assistants and supervised by the coordinators of the study. The structure of each section can be seen in the study by Xavier ${ }^{23}$.

\section{Instruments}

All data were collected by trained and supervised personnel via assessments, one week before and one week after the intervention in both the IG and CG.

The control variables included in the study were known risk factors for cognitive decline found in the literature $\mathrm{e}^{10,11,12,13}$. They included gender, age, marital status, schooling (years of study), and income (more than US\$500 per capita per month versus US\$500 or less). Health control variables included hypertension, diabetes, dyslipidaemia, hypothyroidism, depression, vascular diseases, polymedication (the continuous use of more than three medications), benzodiazepines, exposure to tobacco, sedentary lifestyle (physical activity less than three times per week), and being overweight/obese (body mass index $>27.0 \mathrm{Kg} / \mathrm{m}^{2}$ ).

Functional capacity was measured using the Brazilian Multidimensional Functional Assessment adapted from Older Americans Resources and Services ${ }^{24}$, which consists of 15 questions about basic and instrumental activities of daily living. We calculated the interval, in days, between the date of the first and second assessment. The initial and final cognitive statuses were measured by the MMSE validated in Brazil ${ }^{19}$.

The outcome variable was obtained by calculating the change in percentage between the first MMSE1 and second MMSE (MMSE2), taking into account the ceiling and ground effects according to the following formulae ${ }^{25}$ :

When MMSE2 > MMSE1

$\Delta \mathrm{Y}^{*}=((\mathrm{MMSE} 2-\mathrm{MMSE} 1) /(30-\mathrm{MMSE} 1)) \times 100$

When MMSE2 < MMSE1

$\Delta \mathrm{Y}=((\mathrm{MMSE} 2-\mathrm{MMSE} 1) /(\mathrm{MMSE} 1)) \times 100$

When MMSE2 $=$ MMSE1

$\Delta \mathrm{Y}=0$

* \% Percent change $(\Delta \mathrm{Y})$ between intervals calculated considering 30 points as the roof and the 0 points as the floor.

This outcome variable takes into account the effort in gaining or losing points, valuing variations in the upper and lower limits of the test. It expresses in percentage how much a specific participant gained or lost, in relation to their initial score, and the possible room left for gains or losses.

\section{Data analysis}

We performed descriptive statistics, estimated $\beta$ coefficients and 95\% confidence intervals (CI 95\%), via simple and multiple linear regression, with a significance level of $p \leq 0.05$. Variables with value of $p \leq 0.05$ in the bivariate analysis were included in the final multivariate model.
All analyses were performed using STATA SE 11.0 software (StataCorp. 2009. Stata Statistical Software: Release 11. College Station, TX: StataCorp LP.). Means comparisons of MMSE1 and MMSE2 between the two groups studied were obtained by $\mathrm{T}$ test and ANOVA.

This study fulfilled all ethical principles and was approved by the ethics committee involving human beings. All those involved in the study gave written informed consent.

\section{RESULTS}

From the initial sample of 323 individuals, there were 18 losses among the participants of the IG (those who missed more than $25 \%$ of the sessions), three because of acute disease and 15 because of schedule incompatibility. Among the CG, three refused to perform the second assessment, two were excluded because their assessments were less than 45 days apart, and seven were excluded because of delayed second assessments (interval longer than 365 days).

The sample of 293 participants analysed were $68.50 \pm 6.13$ years of age and had $8.61 \pm 4.47$ years years of schooling (160 in the IG and 133 in the CG). The descriptive characteristics are presented in Table 1 and Table 2.

The IG was significantly younger than the CG, had lower income and was less sedentary. The IG also had a lower dyslipidemia prevalence but higher peripheral arterial insufficiency; the IG group had a tendency to use more medication. There was no significant difference between the groups regarding the MMSE1, functional capacity and schooling. The IG showed significant increase in the MMSE scores from pre-test to post-test evaluations, contrary to the CG, in which the difference in mean MMSE scores between the pre- and post-test was not significant (Table 2).

In terms of overall progress, both groups showed positive variation in the MMSE through the paired samples t test $(\mathrm{IG}=40.48 \pm 40.16$ and $\mathrm{CG}=15.82 \pm 29,99 ; \mathrm{p}=0.000)$. Table 3 shows the crude and adjusted analyses of outcome "percent variation between the MMSE1 and MMSE2”. The IG showed a positive variation +24.39 (CI 95\% 14.86 - 33.91) higher when compared with the CG. Other independent predictors were lower income, and the MMSE1 cognitive status.

\section{DISCUSSION}

The IG showed significant improvement in cognitive status, when compared to the CG.

The MMSE1 score was also an independent factor associated with the outcome: the higher the MMSE1, the more they struggled to improve in the MMSE2, an inverse dependence to the baseline condition. That was possibly due to the fact that people with higher MMSE1 scores are closer to their maximum capacity than the others, resulting in 
Table 1. Caracteristics of the intervention group (IG) and control group (CG) in the pre-test.

\begin{tabular}{|c|c|c|c|}
\hline Variables & $I G(n=160) f(\%)$ & $C G(n=133) f(\%)$ & $p$ \\
\hline \multicolumn{4}{|l|}{ Gender } \\
\hline Male & $27(16.75)$ & $33(24.82)$ & \multirow[t]{2}{*}{0.940} \\
\hline Female & $133(83.15)$ & $100(75.18)$ & \\
\hline \multicolumn{4}{|l|}{ Marital Status } \\
\hline Married & $83(51.87)$ & $80(60.15)$ & \multirow{4}{*}{0.160} \\
\hline Single & $18(11.25)$ & $17(12.78)$ & \\
\hline Separated & $20(12.50)$ & $13(9.77)$ & \\
\hline Widow & 39 (24.37) & $23(17.29)$ & \\
\hline \multicolumn{4}{|l|}{ Monthly income } \\
\hline $\begin{array}{l}\text { US } \$ 500 \text { or less } \\
\text { per month }\end{array}$ & $119(74.38)$ & $80(60.15)$ & \multirow{2}{*}{$0.000 *$} \\
\hline $\begin{array}{l}\text { More than } \\
\text { US } \$ 500 \\
\text { per month }\end{array}$ & $41(25.62)$ & $53(39.85)$ & \\
\hline \multicolumn{4}{|l|}{ Independent } \\
\hline No & $68(42.5)$ & $65(48.87)$ & \multirow[t]{2}{*}{0.270} \\
\hline Yes & $92(57.5)$ & $68(51.13)$ & \\
\hline \multicolumn{4}{|l|}{ Sedentary } \\
\hline No & $90(56.25)$ & $45(43.84)$ & \multirow[t]{2}{*}{$0.000 *$} \\
\hline Yes & $70(43.75)$ & $88(66.16)$ & \\
\hline \multicolumn{4}{|l|}{ Overweight/obese } \\
\hline No & $107(66.88)$ & $98(73.68)$ & \multirow[t]{2}{*}{0.200} \\
\hline Yes & $53(33.12)$ & 35 (26.32) & \\
\hline \multicolumn{4}{|l|}{ Tobacco use } \\
\hline No & $154(96.25)$ & $127(95.49)$ & \multirow[t]{2}{*}{0.740} \\
\hline Yes & $6(3.75)$ & $6(4.51)$ & \\
\hline \multicolumn{4}{|l|}{ Depression } \\
\hline No & $119(74.38)$ & $90(67.67)$ & \multirow[t]{2}{*}{0.200} \\
\hline Yes & $41(25.62)$ & 43 (32.33) & \\
\hline \multicolumn{4}{|l|}{ Vascular disease } \\
\hline No & $141(88.13)$ & $108(81.2)$ & \multirow[t]{2}{*}{0.090} \\
\hline Yes & $19(11.87)$ & $25(18.8)$ & \\
\hline \multicolumn{4}{|l|}{ Hypertension } \\
\hline No & 65 (40.62) & $63(47.37)$ & \multirow[t]{2}{*}{0.240} \\
\hline Yes & 95 (59.38) & 70(52.63) & \\
\hline \multicolumn{4}{|l|}{ Diabetes } \\
\hline No & $128(80)$ & $113(84.96)$ & \multirow[t]{2}{*}{0.260} \\
\hline Yes & $32(20)$ & $20(15.04)$ & \\
\hline \multicolumn{4}{|l|}{ Dyslipidaemia } \\
\hline No & $115(71.88)$ & $78(58.65)$ & $0.001 *$ \\
\hline Yes & $45(28.12)$ & $55(41.35)$ & \\
\hline Peripheral vascula & rinsufficiency & & \\
\hline No & $83(51.7)$ & 89 (67.1) & $0.029 *$ \\
\hline Yes & 77 (48.3) & $44(32.9)$ & \\
\hline Polymedication & & & \\
\hline No & $96(60.0)$ & $92(69.17)$ & 0.051 \\
\hline Yes & $64(40.0)$ & $41(30.83)$ & \\
\hline Benzodiazepines & & & \\
\hline No & $153(95.62)$ & $125(93.98)$ & 0.610 \\
\hline Yes & $7(4.38)$ & $8(6.02)$ & \\
\hline
\end{tabular}

Table 2. Sample characteristics of the intervention group (IG) and control group (CG) in the pre-test and post-test.

\begin{tabular}{|c|c|c|c|}
\hline Variables & $I G(n=160) x \pm S D$ & $C G(n=133) x \pm S D$ & $\mathrm{p}$ \\
\hline $\begin{array}{l}\text { Age. complete } \\
\text { years }\end{array}$ & $67.19 \pm 5.68$ & $69.97 \pm 6.30$ & 0.001 \\
\hline $\begin{array}{l}\text { Years of } \\
\text { schooling }\end{array}$ & $8.29 \pm 4.58$ & $8.95 \pm 4.02$ & 0.180 \\
\hline $\begin{array}{l}\text { MMSE } 1 \\
\text { (pre-test) }\end{array}$ & $25.95 \pm 2.95$ & $26.41 \pm 3.58$ & $0.240^{* *}$ \\
\hline $\begin{array}{l}\text { MMSE2 } \\
\text { (post-test) }\end{array}$ & $27.28 \pm 2.52$ & $26.50 \pm 3.28$ & $0.009^{* \star}$ \\
\hline $\begin{array}{l}\text { Time* between } \\
\text { interviews }\end{array}$ & $131.90 \pm 87.39$ & $206.78 \pm 97.39$ & $0.000 *$ \\
\hline
\end{tabular}

$\mathrm{X}$ : average; SD: standard deviation; $\mathrm{p}$ value for $\mathrm{t}$ test for independent samples; IG: intervention group; CG: control group; MMSE: Mini Mental Status Examination. ${ }^{*}$ Days. ${ }^{*} \mathrm{p}$-value for ANOVA MMSE1 $p=0.322 ;$ MMSE2 $p=0.003$.

less apparent improvement ${ }^{25,26}$; the higher the MMSE1 score, the harder it is to increase the score in the MMSE2 ${ }^{25}$. Schooling was not significant in the analysis; its influence may be too distal, or it's not that important in terms of variation of cognitive status, as both groups had similar schooling levels. However, the monthly income was associated with the study's outcome: the higher the monthly income, the higher the prevalence of gain in the MMSE2. Some studies ${ }^{11-13}$ have shown that really low monthly income can accelerate cognitive problems.

Both groups showed cognitive status improvements throughout the study. These results are in line with Barnes et al. ${ }^{27}$, who reported significant improvement in both groups participating in his controlled study. Several cognitive and functional deficits have reversible causes ${ }^{28}$ and the use of computers is associated with the slowing of cognitive decline and decrease in the incidence of dementia ${ }^{6,7,8,16,17,18,19}$.

A systematic review study ${ }^{9}$ that analyzed 84 research studies aiming to evaluate different types of cognitive rehabilitation programs, showed that the use of computers improves creativity, cognitive flexibility, attention, task execution, executive functions, episodic memory and other cognitive abilities.

The main strengths of this study are the low attrition, the percent variation used to address the ceiling effect bias and the medical follow-up.

Among the limitations of the study is the fact that the participants were not randomized, which fosters the occurrence of selection bias. The IG was younger, more active, poorer, and had less dyslipidemia. Age advancement ${ }^{9}$, physical inactivity ${ }^{9,10}$, dyslipidemia ${ }^{10}$ and low schooling ${ }^{11,12,13}$ are factors that may influence MMSE scores.

The fact that both groups showed a positive variation in the outcomes studied also can be considered a study limitation. This may be due to learning bias in the cognitive testing and/or due to the medical follow-up offered to both groups. There was also a significant difference in the elapsed time between the first and second assessment of both groups. 
Table 3. Crude and adjusted analysis of the effect of the cognitive cooperation program percent variation.

\begin{tabular}{|c|c|c|c|c|}
\hline \multirow{2}{*}{ Variable } & \multicolumn{2}{|c|}{ Crude analysis } & \multicolumn{2}{|c|}{ Adjusted analysis } \\
\hline & Coefficient (Cl 95\%) & $\mathrm{p}$ & Coefficient (Cl 95\%) & $\mathrm{p}$ \\
\hline IG & $23.62(15.32 / 31.91)$ & 0.000 & $24.39(14.86 / 33.91)$ & 0.000 \\
\hline Age & $-0.59(-1.31 / 0.11)$ & 0.090 & $-0.61(-1.37 / 0.14)$ & 0.110 \\
\hline Gender & $-4.63(-15.34 / 6.07)$ & 0.395 & $4.9(-5.77 / 15.58)$ & 0.360 \\
\hline Physical actitivty at least $3 \times$ week & $-3.19(-11.9 / 5.5)$ & 0.470 & -- & -- \\
\hline Independent & $-4.54(-13.26 / 4.17)$ & 0.300 & -- & -- \\
\hline Overweight/obese & $-5.44(-14.87 / 3.97)$ & 0.250 & -- & -- \\
\hline Monthly income & $10.33(1.6 / 19.05)$ & 0.002 & $19.97(2.73 / 37.21)$ & 0.002 \\
\hline Depression & $2.42(-7.21 / 12.06)$ & 0.620 & -- & -- \\
\hline Vascular diseases & $-13.79(-25.91 /-1.67)$ & 0.002 & $-14.63(-30.7 / 24.75)$ & 0.422 \\
\hline Hypertension & $-5.44(-14.16 / 3.28)$ & 0.220 & -- & -- \\
\hline Diabetes & $2.67(-8.73 / 14.07)$ & 0.641 & -- & -- \\
\hline High cholesterol & $-0.63(-9.81 / 8.54)$ & 0.890 & -- & -- \\
\hline Tobacco use & $7.09(-15.63 / 29.82)$ & 0.533 & -- & -- \\
\hline Schooling & $-0.54(-1.52 / 0.43)$ & 0.270 & -- & -- \\
\hline Time between interviews & $-0.03(-0.77 / 0.01)$ & 0.130 & -- & -- \\
\hline MMSE1 & $-3.45(-4.72 /-2.17)$ & 0.000 & $-4.28(-5.68 /-2.88)$ & 0.000 \\
\hline
\end{tabular}

IG: Intervention group; CI 95\%: 95\% confidence interval; MMSE1: first mini mental status examination.

This limitation was addressed by its use as a control variable, and by the fact that, initially, there were no participants with dementia, who typically present faster rates of decline. Another limitation of the study is the use of a single cognitive tracking test, considering that other instruments might have been better at detecting differences between pre-test and post-test conditions. The sample studied refers to a specific group and can not be generalized.

In conclusion, the results this study suggest that cognitive cooperation groups mediated by computers and the internet are associated with cognitive status improvement in community dwelling older adults attending memory clinics.

\section{References}

1. Fonseca JA, Ducksbury R, Rodda J, Whitfield T, Nagaraj C, Suresh $\mathrm{K}$ et al. Factors that predict cognitive decline in patients with subjective cognitive impairment. Int Psychogeriatr. 2015;27(10):1671-7. https://doi.org/10.1017/S1041610215000356

2. Verdelho A, Madureira S, Moleiro C, Santos CO, Ferro JM, Erkinjuntti Tet al. Self-perceived memory complaints predict progression to Alzheimer disease: the LADIS study. J Alzheimer's Dis. 2011;27(3):491-8. https://doi.org/10.3233/JAD-2011-110494

3. Singh-Manoux A, Kivimaki M, Glymour MM, Elbaz A, Berr C, Ebmeier KP et al. Timing of onset of cognitive decline: results from Whitehall II prospective cohort study. BMJ. 2012;344:d7622. https://doi.org/10.1136/bmj.d7622

4. Jolley D, Moniz-Cook E. Memory clinics in context. Indian J Psychiatry. 2009;51(Suppl 1):S70-6.

5. Moniz-Cook E, Vernooij-Dassen M, Woods B, Orrell M. Psychosocial interventions in dementia care research: the INTERDEM manifesto. Aging Ment Health. 2011;15(3):283-90. https://doi.org/10.1080/13607863.2010.543665

6. Woods B, Aguirre E, AE Spector, Orrell M. Cognitive stimulation to improve cognitive functioning in people with dementia. Cochrane Database Syst Rev. 2012;(2):CD005562. https://doi.org/10.1002/14651858.CD005562.pub2

7. Cotelli M, Manenti R, Zanetti O, Miniussi C. Non-pharmacological intervention for memory decline. Front Hum Neurosci. 2012:6:46. https://doi.org/10.3389/fnhum.2012.00046
8. Jean L, Bergeron ME, Thivierge S, Simard M. Cognitive intervention programs for individuals with mild cognitive impairment: systematic review of the literature. Am J Geriatr Psychiatry. 2010;18(4):281-96. https://doi.org/10.1097/JGP.0b013e3181c37ce9

9. Diamond A, Ling DS. Conclusions about interventions, programs, and approaches for improving executive functions that appear justified and those that, despite much hype, do not. Dev Cogn Neurosci. 2016;18:34-48. https://doi.org/10.1016/j.dcn.2015.11.005

10. Norton S, Matthews FE, Barnes DE, Yaffe K, Brayne C. Potential for primary prevention of Alzheimer's disease: an analysis of population-based data. Lancet Neurol. 2014;13(8):788-94. https://doi.org/10.1016/S1474-4422(14)70136-X

11. Matthews FE, Arthur A, Barnes LE, Bond J, Jagger C, Robinson L et al. A two-decade comparison of prevalence of dementia in individuals aged 65 years and older from three geographical areas of England: results of the Cognitive Function and Ageing Study I and II. Lancet. 2013;382(9902):1405-12. https://doi.org/10.1016/S0140-6736(13)61570-6

12. Fratiglioni L, Qiu C. Prevention of cognitive decline in ageing: dementia as the target, delayed onset as the goal. Lancet Neurol. 2011;10(9):778-9. https://doi.org/10.1016/S1474-4422(11)70145-4

13. Lincoln P, Fenton K, Alessi C, Prince M, Brayne C, Wortmann $\mathrm{M}$ et al. The Blackfriars Consensus on brain health and dementia. Lancet. 2014;383(9931):1805-6. https://doi.org/10.1016/S0140-6736(14)60758-3 
14. Ngandu T, Lehtisalo J, Solomon A, Levälahti E, Ahtiluoto S, Antikainen $R$ et al. Articles A 2 year multidomain intervention of diet, exercise, cognitive training, and vascular risk monitoring versus control to prevent cognitive decline in at-risk elderly people (FINGER): a randomised controlled trial. Lancet. 2015;385(9984):2255-63. https://doi.org/10.1016/S0140-6736(15)60461-5

15. Xavier AJ, d'Orsi E, Wardle J, Demakakos P, Smith SG, Wagner $\mathrm{C}$. Internet use and cancer-preventive behaviors in older adults: findings from a longitudinal cohort study. Cancer Epidemiol Biomarkers Prev. 2013;22(11):2066-74. https://doi.org/10.1158/1055-9965.EPI-13-0542

16. Almeida OP, Yeap BB, Alfonso H, Hankey GJ, Flicker L, Norman PE. Older men who use computers have lower risk of dementia. PLoS One. 2012;7(8):e44239. https://doi.org/10.1371/journal.pone.0044239

17. Paiva SB, Del-Masso MCS. Information technology as a technical resource for the memories: memories of unati-marilia in the virtual environment. J Inf Syst Technol Manag. 2013;10(2):377-88. https://doi.org/10.4301/S1807-17752013000200011

18. Xavier AJ, d'Orsi E, Oliveira CM, Orrell M, Demakakos P, Biddulph JP et al. English longitudinal study of aging: can internet/E-mail use reduce cognitive decline? J Gerontol A Biol Sci Med Sci. 2014;69(9):1117-21. https://doi.org/10.1093/gerona/glu105.

19. Lourenço RA, Veras RP. Mini-Mental State Examination: psychometric characteristics in elderly outpatients. Rev Saúde Pública. 2006;40(4):712-9. https://doi.org/10.1590/S0034-89102006000500023

20. Lee GY, Yip CC, Yu EC, Man DW. Evaluation of a computer-assisted errorless learning-based memory training program for patients with early Alzheimer's disease in Hong Kong: a pilot study. Clin Interv Aging. 2013;8:623-33. http://doi.org/10.2147/CIA.S45726
21. Frith $\mathrm{CD}$. The role of metacognition in human social interactions. Philos Trans R Soc Lond B Biol Sci. 2012;367(1599):2213-23. https://doi.org/10.1098/rstb.2012.0123

22. Krug RR, Ono LM, Quialheiro A, d'Orsi E, Ramos LR, Xavier AJ. A Stimulation and rehabilitation program: oficina da lembrança. Rev Bras Ativ Fis Saúde. 2015;20(5):534-40. https://doi.org/10.12820/rbafs.v.20n5p534

23. Xavier AJ. Estado cognitivo, capacidade funcional e o processo de inclusão digital de idosos [thesis]. São Paulo: Universidade Federal de São Paulo; 2007.

24. Ramos LR. [Determinant factors for healthy aging among senior citizens in a large city: the Epidoso Project in São Paulo]. Cad Saúde Pública. 2003;19:793-8. Portuguese. https://doi.org/10.1590/S0102-311X2003000300011

25. Hesket R, Skrondal A. A review of multilevel and longitudinal modeling using stata. J Educ Behav Stat. 2009;34(3):559-60.

26. La Rue A. Healthy brain aging: role of cognitive reserve, cognitive stimulation, and cognitive exercises. Clin Geriatr Med. 2010;26(1):99-111. https://doi.org/10.1016/j.cger.2009.11.003

27. Barnes DE, Santos-Modesitt W, Poelke G, Kramer AF, Castro C, Middleton LE et al. The Mental Activity and eXercise (MAX) trial: a randomized controlled trial to enhance cognitive function in older adults. JAMA Intern Med. 2013;173(9):797-804. https://doi.org/10.1001/jamainternmed.2013.189

28. d'Orsi E, Xavier AJ, Steptoe A, Oliveira C, Ramos LR, Orrell M et al. Socioeconomic and lifestyle factors related to instrumental activity of daily living dynamics: results from the English Longitudinal Study of Ageing. J Am Geriatr Soc. 2014;62(9):1630-9. https://doi.org/10.1111/jgs.1299 